\title{
Generic Cyclosporine in the Treatment of Dry Eye Disease
}

\author{
C. Banu Coşar ${ }^{1,2}$ (iD , A. Ebru Kılavuzoğlu ${ }^{1,2}$ (iD) , A. R. Cenk Çelebi ${ }^{1,3}$ (ID , \\ U. Emrah Altıparmak ${ }^{4}$ iD
}

${ }^{1}$ Acibadem Mehmet Ali Aydinlar University, Ophthalmology Clinic, Istanbul, Turkey

${ }^{2}$ Acibadem Maslak Hospital, Ophthalmology Clinic, Istanbul Turkey

${ }^{3}$ Acibadem Atakent Hospital, Ophthalmology Clinic, Istanbul, Turkey

${ }^{4}$ Acibadem Ankara Hospital, Ophthalmology Clinic, Ankara, Turkey

\section{Banu COŞAR}

\section{A. Ebru KILAVUZOĞLU}

A. R. Cenk ÇELEBi

U. Emrah ALTIPARMAK

Correspondence: C. Banu Coşar Acibadem Maslak Hospital, Ophthalmology Clinic, Istanbul Turkey

Phone: +905056731840

E-mail: cbcosar@yahoo.com

\section{ABSTRACT}

Objectives: To investigate the efficacy and safety of a generic Cyclosporine $0.05 \%$ ophthalmic emulsion in chronic dry eye disease.

Materails and Methods: Thirty patients with dry eye disease were included in this observational, prospective study. Patients were examined at baseline, at month $-1,-3$ and 6 of the study. The following were evaluated at each visit: CDVA (corrected distance visual acuity), corneal and conjunctival staining (0xford) score, TBUT (tear break-up time), Schirmer-2 score, OSDI (Ocular Surface Disease Index) score, patient's subjective rating scale of ocular discomfort, daily use of concomittant artificial tears, the researcher's assessment of the global treatment response, and IOP (intraocular pressure). In addition, drug-related side effects were evaluated individually in each examination. When initiating dry eye treatment, cyclosporine was combined with topical loteprednol etabonate $0.5 \%$.

Results: There was a statistically significant improvement from baseline in corneal and conjunctival staining (decrease in mean 0xford score), TBUT, Schirmer-2 values, OSDI score, patient's subjective rating score for ocular discomfort, and mean physician's subjective assessment of global response to treatment at all follow-up visits $(p<0.001)$. The mean daily use of artifical drops decreased statistically at all time points $(<0.001)$. The most commonly reported adverse events were ocular burning (6.7\%), followed by stinging (3.3\%), conjunctival hyperemia (3.3\%), foreign body sensation (3.3\%), and visual disturbance (3.3\%).

Conclusion: Generic cyclosporine $0.05 \%$ ophthalmic emulsion with loteprednol etabonate $0.5 \%$ on initiation treatment has well-tolerability and improves subjective and objective measures of dry eye disease.

Keywords: Dry eye syndromes, cyclosporine, generic equivalency

\section{Kuru Göz Hastalığının Tedavisinde Jenerik Siklosporin}

ÖZET

Amaç: Jenerik \%0.05 siklosporin oftalmik emülsiyonunun kronik kuru göz hastalığındaki etkinliğini ve güvenliğini araştırmak.

Gereç ve Yöntem: Kuru göz hastalığı olan 30 hasta, bu gözlemsel prospektif çalışmaya dahil edildi. Hastalar başlangıçta, çalışmanın 1., 3. ve 6. ayında değerlendirildi. Çalışmada değerlendirilen parametreler şunlardı: DUGK (düzeltilmiş uzak görme keskinliği), korneal ve konjonktival boyanma (0xford) skoru, GKZ (gözyaşı kırılma zamanı), Schirmer-2 skoru, OSDI (oküler yüzey hastalık indeksi) skoru, GiB (göziçi basıncı), günlük suni gözyașı kullanım miktarı, araştırmacının global tedavi cevabını değerlendirmesi ve oküler rahatsızıı için hastanın subjektif değerlendirme skoru. Ayrıca, her muayenede ilaçla ilişkili yan etkiler değerlendirildi. Kuru göz tedavisinin başlangııında, siklosporinle birlikte topikal \%05 loteprednol etabonat kombine edildi.

Bulgular: Korneal ve konjonktival boyanma, GKZ, Schirmer-2 değerleri, OSDI skoru, hastanın subjektif değerlendirme skoru ve araştırmacının global tedavi cevabını değerlendirmesi; başlangıç seviyesine kıyasla her vizitte düzelmiş olarak bulundu ( $p<0.001)$. Her vizitte, günlük suni gözyaşı kullanımı da düşmüş olarak bulundu $(p<0.001)$. En sık bildirilen ilaçla ilişkili yan etkiler; oküler yanma (\%6.7), batma (\%3.3), konjonktival hiperemi (\%3.3), yabancı cisim hissi (\%3.3), ve görme bozukluğu (\%3.3) idi.

Sonuç: Başlangıç tedavisinde $\% 0.5$ loteprednol etabonat ile kombinlenmiş jenerik $\% 0.05$ siklosporin oftalmik emülsiyonu, iyi tolere edilmekte ve kuru gözün subjektif ve objektif ölçeklerini iyileştirmektedir.

Anahtar Kelimeler: Kuru göz sendromları, siklosporin, jenerik eşdeğerlik 
Dry eye is a multifactorial disease of the ocular surface characterized by a loss of homeostasis of the tear film, and accompanied by ocular symptoms, in which tear film instability and hyperosmolarity, ocular surface inflammation and damage, and neurosensorial abnormalities play etiological roles" as defined by Tear Film and Ocular Surface Society Dry Eye Workshop 2 Study Group (1).

Tear replacement with ocular lubricants or artificial tears is the mainstay of dry eye diseease (DED) treatment. However, these products do not target the underlying pathophysiology of DED and the symptomatic relief they provide is temporary. Desiccating stress can induce ocular surface damage and generate innate and adaptive immune responses. These inflammatory cascades lead to further ocular surface damage and the development of a self-perpetuating inflammatory cycle (2).

Cyclosporine is an immunomodulatory drug with antiinflammatory properties, as well as other properties to manage DED (3-5). Cyclosporine inhibits IL-2 activation of lymphocytes (5). Treatment with cyclosporine reduces many markers of inflammation $(6,7)$ and also reduces elevated tear osmolarity (8). Cyclosporine also has antiapoptotic effects establishing the normal epithelial cell/ leukocyte relationship in $\operatorname{DED}(9,10)$. Additionally, cyclosporine treatment results in recovery of reduced goblet cell density in the conjunctiva of subjects with $\operatorname{DED}(11,12)$.

The first topical cyclosporine A commercially available in 2000 was Restasis (Cyclosporine A 0.05\%, Allergan, USA). Restasis was approved by the FDA for the treatment of moderate-to-severe DED in 2003, based on an improvement in tear production measured by the Schirmer test in $15 \%$ of patients, compared to $5 \%$ of vehicle-treated controls (2). Depores (cyclosporine 0.05\%, Deva Pharmaceuticals, Turkey) is a generic cyclosporine $0.05 \%$ ophthalmic emulsion which became commercially available in Turkey in 2013. In this study, we evaluated the efficacy and safety of this generic CsA $0.05 \%$ in chronic dry eye patients.

\section{MATERIAL AND METHODS}

Thirty patients with dry eye disease were included in this observational, prospective study. The study was performed according to the guidelines of the Helsinki Declaration and approved by the institutional ethics committee (Acibadem Mehmet Ali Aydinlar University Medical Research Ethics Committee, 14.01.2016, 2016/1).
Informed consent was given by all patients. The inclusion criteria were age $>18$ years and symptomatic dry eye disease in which artificial tears and gels were not sufficient. Exclusion criteria were use of systemic or topical CsA in the previous 90 days, women who were pregnant/planning a pregnancy or lactating, active ocular infections and suspected hypersensitivity to any of the ingredients in the CsA formulation.

Patients were examined at baseline, at month $-1,-3$ and -6 of treatment. The following were evaluated at each visit: CDVA (corrected distance visual acuity), corneal and conjunctival fluorescein staining (Oxford) score, tear break-up time, Schirmer score, OSDI (Ocular Surface Disease Index) score, IOP (intraocular pressure, by air-puff tonometry), and daily use of concomittant artificial tears, the researcher's assessment of the global treatment response (0: full recovery, 1: $90 \%$ improvement, 2: $75 \%$ improvement, $4: 25 \%$ improvement, 5: no change, 6: worsening), patient's subjective rating scale ( 0 to 4 ) of ocular discomfort (stinging/ burning, itching, sandiness/grittiness, blurred vision, light sensitivity, pain or soreness). In addition, drug-related side effects were evaluated individually in each examination: Burning, stinging, conjunctival hyperemia, foreign body sensation, blurred vision, eye pain, and other if any.

When initiating dry eye treatment, cyclosporine A was combined with loteprednol etabonate. Patients received topical CsA \%0.05 (Depores, Deva Pharmaceuticals, Turkey) twice daily and artificial tears (sodium hyaluronate) as needed. Topical loteprednol 0.5\% (Lotemax, Bausch and Lomb, USA) was given for 4 weeks, started as QID for the first 2 weeks and BID for the following 2 weeks. Compliance with the treatment regimen was assessed by patient interview at each visit.

Only the data from the "worse" eye were included in the analyses for efficacy variables. The "worse" eye was defined as the eye with the worse Schirmer (with anesthesia) value and the worse sum of corneal and conjunctival staining. If both eyes are similar, then the right eye was used. The "worse" eye was identified at baseline measurements, and data from this eye were used for all subsequent analyses. However, all safety analyses included data from both eyes.

IBM SPSS Statistics 25.0 statistical software (IBM, USA) was used for statistical analysis. Normality of difference scores for three or more observations was assessed using skewness and kurtosis statistics. Descriptive statistics 
(arithmetic mean \pm standard error) and repeated measures of analysis of variance were used for statistical analyses. A p value of less than 0.05 was considered as statistically significant.

\section{RESULTS}

Of the thirty patients, $22(73.3 \%)$ were females and 8 (26.7\%) were males. The average age was $47.3 \pm 1.4$ (3464) years. The clinical findings of the patients are summarized in Table 1.

\section{Corneal and Conjunctival Staining}

At baseline, the mean Oxford score for corneal staining was $2.6 \pm 0.11$ (1-4). There was a statistically significant improvement from baseline in corneal staining (decrease in mean Oxford score) at all follow-up visits $(p<0.001)$.

At baseline, the mean Oxford score for nasal interpalpebral conjunctival staining was $2.3 \pm 0.14$ (1-4). There was a statistically significant improvement from baseline in nasal interpalpebral conjunctival staining (decrease in mean Oxford score) at all follow-up visits $(p<0.001)$.

At baseline, the mean Oxford score for temporal interpal-

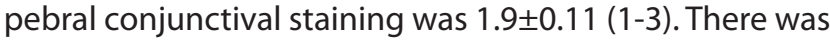
a statistically significant improvement from baseline in temporal interpalpebral conjunctival staining (decrease in mean Oxford score) at al follow-up visits $(p<0.001)$.

\section{Tear Break Up Time (TBUT)}

At baseline, the mean TBUT was 3.7 \pm 0.3 (1-9). There was a statistically significant improvement from baseline in TBUT at all follow-up visits $(p<0.001)$.

\section{Schirmer Tear Test}

At baseline, the mean Schirmer values (obtained with anesthesia) was $6.0 \pm 0.4$. There was a statistically significant improvement from baseline in Schirmer values at all follow-up visits $(p<0.001)$.

\section{OSDI Score}

The OSDI score, evaluating the impact of patient's dry eye disease on vision-related functioning, was 40.6 1.9 (22.938.5) at baseline, $23.0 \pm 1.4(12.5-45.8)$ at month 1, 15.3 \pm 1.4 (12.5-45.8) at month 3 and 8,0 0.8 (1.5-18.7) at month 6 . The improvement in OSDI score was statistically significant at all time points $(p<0.001)$.

\section{Patient's Subjective Rating Scale}

The mean patient's subjective rating score for ocular discomfort (stinging/burning, itching, sandiness/grittiness, blurred vision, light sensitivity, pain or soreness) was $2.2 \pm 0.15$ (1-4) at baseline. Statistically significant changes from baseline were observed at all time points in patient's subjective rating scale $(p<0.001)$.

\section{Daily Use of Concomitant Artificial Tears}

The mean daily use of artifical drops was $5.5 \pm 0.29$ (3-9) at baseline, $2.8 \pm 0.19(1-5)$ at month 1, 1.8 $\pm 0.12(0-2)$ at month 3 and $1.0 \pm 0.12(0-2)$ at month 6 . There were statistically significant decreases in the frequency of artificial tear use at all time points $(p<0.001)$.

\begin{tabular}{|c|c|c|c|c|c|}
\hline & Baseline & $\begin{array}{l}\text { Post-treatment } \\
\text { month } 1\end{array}$ & $\begin{array}{l}\text { Post-treatment } \\
\text { month } 3\end{array}$ & $\begin{array}{l}\text { Post-treatment } \\
\text { month } 6\end{array}$ & $\mathbf{p}$ \\
\hline Corneal Staining & $2.6 \pm 0.11(1-4)$ & $1.0 \pm 0.12(0-2)$ & $0.5 \pm 0.11(0-2)$ & $0.2 \pm 0.08(0-1)$ & $<0.001$ \\
\hline $\begin{array}{l}\text { Conjunctival Staining } \\
\text { Nasal } \\
\text { Temporal }\end{array}$ & $\begin{array}{l}2.3 \pm 0.14(1-4) \\
1.9 \pm 0.11(1-3)\end{array}$ & $\begin{array}{l}0.8 \pm 0.11(0-2) \\
0.6 \pm 0.09(0-1)\end{array}$ & $\begin{array}{l}0.3 \pm 0.08(0-1) \\
0.6 \pm 0.09(0-1)\end{array}$ & $\begin{array}{l}0.1 \pm 0.06(0-1) \\
0.1 \pm 0.06(0.1)\end{array}$ & $\begin{array}{l}<0.001 \\
<0.001\end{array}$ \\
\hline Tear Break Up Time (sec) & $3.7 \pm 0.3(1-9)$ & $7.3 \pm 0.3(1-11)$ & $9.2 \pm 0.2(7-13)$ & $11.3 \pm 0.3(8-15)$ & $<0.001$ \\
\hline Schirmer Score (mm) & $6.0 \pm 0.4(1-11)$ & $7.3 \pm 0.4(3-12)$ & $8.8 \pm 0.3(5-12)$ & $9.8 \pm 0.3(8-14)$ & $<0.001$ \\
\hline OSDI Score & $40.6 \pm 1.9(22.9-38.5)$ & $23.0 \pm 1.4(12.5-45.8)$ & $15.3 \pm 1.4(12.5-45.8)$ & $8.0 \pm 0.8(1.5-18.7)$ & $<0.001$ \\
\hline Patient's Subjective Rating Scale & $2.2 \pm 0.15(1-4)$ & $1.2 \pm 0.122(0-2)$ & $0.5 \pm 0.09(1-5)$ & $0.5 \pm 0.11(0-2)$ & $<0.001$ \\
\hline Daily Use of Artificial Tears & $5.5 \pm 0.29(3-9)$ & $2.8 \pm 0.19(1-5)$ & $1.8 \pm 0.12(0-2)$ & $1.0 \pm 0.12(0-2)$ & $<0.001$ \\
\hline Global Treatment Response & - & $2.5 \pm 0.2(1-5)$ & $1.6 \pm 0.1(1-3)$ & $0.5 \pm 0.1(0-1)$ & $<0.001$ \\
\hline CDVA (logmar) & $0.03 \pm 0.01(0.00-0.20)$ & $0.02 \pm 0.01(0.00-0.20)$ & $0.00+0.00(0.00-0.10)$ & $0.00+0.00(0.00-0.10)$ & $<0.001$ \\
\hline IOP (mmHg) & $15.5 \pm 0.4(12-20)$ & $15.8 \pm 0.4(12-20)$ & $16.2 \pm 0.3(13-21)$ & $15.7 \pm 0.4(11-20)$ & 0.654 \\
\hline
\end{tabular}


Researcher's Assesment of the Global Treatment Response

The mean researcher's assessment of the global response to treatment was $2.5 \pm 0.2(1-5)$ at month $1,1.6 \pm 0.1$ (1-3) at month 3 and $0.5 \pm 0.1(0-1)$ at month 6 . Statistically significant improvements in physician's subjective assesment of global response to treatment were observed at all time points $(p<0.001)$.

\section{Adverse Events}

The most common adverse event reported was ocular burning $(6.7 \%)$, followed by stinging $(3.3 \%)$, conjunctival hyperemia (3.3\%), foreign body sensation (3.3\%), and visual disturbance (3.3\%). No other adverse effects were noted.

\section{DISCUSSION}

The molecular formula of cyclosporine is $\mathrm{C}_{62} \mathrm{H}_{111} \mathrm{~N}_{11} \mathrm{O}_{12}$, it is a non-ribosomal peptide containing d-amino acid. The water solubility of cyclosporine is low and its absorption by the cell is variable (13). Cyclosporine can be given to the eye in the form of aqueous drops, but the low dissolution of cyclosporine limits its penetration. Emulsions provide effective topical ophthalmic delivery system with a potential for sustained drug release. In Restasis, $0.05 \%$ castor oil is included in the water emulsion. Various other delivery systems are under investigation $(14,15)$.

CsA ophthalmic solution (Restasis) was originally approved by the US Food and Drug Administration for the management of moderate-to severe keratoconjunctivitis sicca (KCS) (severity levels 2-3 in the DEWS guidelines). However, it has been shown that patients with mild dry eye (severity level 1 in the DEWS guidelines) may also benefit from CsA treatment that may reduce the progression of DED severity $(16,17)$. DEWS II cautioned that the management algorithm proposed in their report did not represent rigid stepwise approach (2). In our study, we used topical Cyclosporine whenever the artifical tears or gels were not enough to relieve the symptoms. We did not classify patients according to the type of the dry eye and this might be a limitation of the study.

In Turkey, European Medicine Agency (EMA) rules are applicable for companies to market generic medicines. A generic medicine contains the same active substance as the reference medicine, and it is used at the same dose(s) to treat the same disease. However, a generic medicine's inactive gradients, name, appearance and packaging can be different. Generic medicines are manufactured according to the same quality standards as all other medicines.
Since information on the safety and efficacy of the active substance is already available from the reference medicine, companies producing generic medicines usually only need to provide information on the quality of medicine and demonstrate that the generic medicine produces the same levels of the active substance in the human body as the reference medicine. After they have been authorised, the authorites monitor the safety of generic medicines (18). However, many ophthalmologists are concerned about the clinical performance of generic products because of the different pathways that generic and branded ophthalmic medications follow to gain approval (19). Based on this concern, the clinical performance of Depores, a generic CsA $0.05 \%$, has been investigated in this study. To our knowledge, there is no previous clinical study evaluating the efficacy and safety of this generic emulsion.

Several studies and meta-analyses have been published that support the efficacy of cyclosporine in the management of DED (20-23). In multicenter, randomized, double-masked Phase 3 study of Restasis, treatment with CsA $0.05 \%$ gave significantly greater improvements than vehicle in two objective signs of dry eye disease (corneal staining and categorized Schirmer values). CsA 0.05\% treatment also gave significantly greater improvements in three subjective measures of dry eye disease (blurred vision, need for concomitant artificial tears, and the physician's evaluation of global response to treatment). The results of this Depores study are consistent with Phase 3 study of Restasis. Treatment with Depores significantly improved all subjective and objective parameters including corneal staining, Schirmer values, blurred vision, need for concomitant artificial tears, and the physician's evaluation of global response to treatment. In this study, we used loteprednol acetate on initiation treatment for a month and this might have played an enhancing role in improvement of signs and symptoms of DED. In a prospective, double-masked, multicenter randomized controlled trial, $0.5 \%$ loteprednol therapy two weeks before the initiation of long-term topical $0.05 \%$ cyclosporine provided more rapid improvement in Schirmer score, corneal fluorescein staining, lissamine green staining, and symptoms, than topical cyclosporine or artificial tears alone (24). In another prospective study, there was greater reduction in OSDI score, corneal staining, and improvement in TBUT and Schirmer's test values in the group receiving combination of loteprednol $0.5 \%$ as compared to the group receiving CsA alone (25). 
Topical CsA treatment exhibited a very low rate of of adverse events, and those events seen were mostly mild to moderate. In clinical trials, the most common adverse reaction following the use of Restasis was ocular burning (17\%). Other reactions reported in $1 \%$ to $5 \%$ of patients included conjunctival hyperemia, discharge, epiphora, eye pain, foreign body sensation, pruritus, stinging, and visual disturbance (most often blurring) (26). In our study, only 2 patients (6.7\%) developed burning and 1 patient developed stinging (3.3\%), possibly due to initiation treatment with loteprednol as the active/inactive ingredients and $\mathrm{pH}$ range of the both formulations (Restasis and Depores) are similar. Previous studies also reported reduced cyclosporine stinging with topical loteprednol $(24,25,27)$. A 36-month extension trial reported lower burning sensation than previously reported in two Phase III 12-month clinical trials suggesting that the side effects are reduced by the improved ocular surface (20). Less stinging in our study might also be related with the level of ocular surface dryness at baseline. There are no systemic side effects in topical use of CsA because very little amount passes into the bloodstream after topical application $(14,22)$.

This study has some limitations such as relatively small number of participants and lack of a control group. However, the study addresses an important issue regarding the clinical performance of a generic CsA ophthalmic emulsion and demonstrated its' efficacy and safety.

\section{CONCLUSION}

Depores ophthalmic emulsion twice-a-day with loteprednol etabonate on initiation treatment has well-tolerability and improves subjective and objective measures of dry eye disease.

\section{ACKNOWLEDGEMENTS}

\section{Conflicts of Interest: None}

\section{REFERENCES}

1. Craig JP, Nichols KK, Akpek EK, et al. TFOS DEWS II definition and classification report. Ocul Surf 2017; 15: 276-83.

2. Jones L, Downie LE, Korb D, et al. TFOS DEWS II management and therapy report. Ocul Surf 2017; 15: 575-628.

3. J.M. Barbarino, C.E. Staatz, R. Venkataramanan, T.E. Klein, R.B. Altman. PharmGKB summary: cyclosporine and tacrolimus pathways. Pharmacogenet Genomics 2013; 23: 563-85.

4. E. Donnenfeld, S.C. Pflugfelder. Topical ophthalmic cyclosporine: pharmacology and clinical uses. Surv Ophthalmol 2009; 54: 321-38.

5. S. Matsuda, S. Koyasu. Mechanisms of action of cyclosporine. Immunopharmacology 2000; 47: 119-25.
6. Kunert KS, Tisdale AS, Stern ME, Smith JA, Gipson IK. Analysis of topical cyclosporine treatment of patients with dry eye syndrome: effect on conjunctival lymphocytes. Arch Ophthalmol 2000; 118: 1489-96.

7. Brignole F, Pisella PJ, De Saint Jean M, Goldschild M, Goguel A, Baudouin C. Flow cytometric analysis of inflammatory markers in KCS: 6-month treatment with topical cyclosporine A. Invest Ophthalmol Vis Sci 2001; 42: 90-5.

8. Sullivan BD, Crews LA, Sönmez B, de la Paz MF, Comert E, Charoenrook $\mathrm{V}$, et al. Clinical utility of objective tests for dry eye disease: variability over time and implications for clinical trials and disease management. Cornea 2012; 31: 1000-8.

9. Gao J, Sana R, Calder V, Calonge M, Lee W, Wheeler LA, et al. Mitochondrial permeability transition pore in inflammatory apoptosis of human conjunctival epithelial cells and T cells: effect of cyclosporine A. Invest Ophthalmol Vis Sci 2013; 54: 4717-33.

10. K. Tsubota, H. Fujita, K. Tadano, T. Takeuchi, T. Murakami, I. Saito, et al. Improvement of lacrimal function by topical application of CyA in murine models of Sjögren's syndrome. Invest Ophthalmol Vis Sci 2001; 42: 101-10.

11. Sall K, Stevenson OD, Mundorf TK, Reis BL. Two multicenter, randomized studies of the efficacy and safety of cyclosporine ophthalmic emulsion in moderate to severe dry eye disease. CsA Phase 3 Study Group, Ophthalmology 2000; 107: 631-9.

12. Pflugfelder SC, De Paiva CS, Villarreal AL, Stern ME. Effects of sequential artificial tear and cyclosporine emulsion therapy on conjunctival goblet cell density and transforming growth factorbeta2 production. Cornea 2008; 27: 64-9.

13. El tayar $\mathrm{N}$, Mark $\mathrm{AE}$, Vallat $\mathrm{P}$, et al. Solvent-dependent conformation and hydrogen-bonding capacity of cyclosporine A: evidence from partition coefficients and molecular dynamics simulations. J Med Chem 1993; 36: 3757-64.

14. Schulltz C. Safety and efficacy of cyclosporine in the treatment of chronic dry eye. Ophthalmol Eye Dis 2014; 6: 37-42.

15. Patel D, Wairkar S. Recent advances in cyclosporine drug delivery. Challenges and opportunities. Drug Delivery and Translational Research 2019; 9: 1067-81.

16. Perry $H$, Solomon R, Donnenfeld ED, et al. Evaluation of topical cyclosporine for the treatment of dry eye disease. Arch Ophthalmol 2008; 126: 1046-50.

17. Oliveira RC, Wilson SE. Practical guidance for the use of cyclosporine ophthalmic solutions in the management of dry eye disease. Clin Ophthalmol 2019; 13: 1115-22.

18. European Medicines Agency, Generic and Hybrid Medicines. Available at: https://www.ema.europa.eu/en/human-regulatory/ marketing-authorisation/generic-hybrid-medicines

19. Branded vs. Generics: You make the call. Ophthalmology Times. December 6, 2018. Available at: https://www.ophthalmologytimes. com/article/branded-vs-generics-you-make-call

20. Barber LD, Pflugfelder SC, Tauber J, Foulks GN. Phase III safety evaluation of cyclosporine $0.1 \%$ ophthalmic emulsion administered twice daily to dry eye disease patients for up to 3 years. Ophthalmology 2005; 112: 1790-4.

21. Holland EJ, Darvish M, Nichols KK, Jones L, Karpecki PM. Efficacy of topical ophthalmic drugs in the treatment of dry eye disease: $A$ systematic literature review. Ocul Surf 2019; 17: 412-23.

22. Wan $\mathrm{KH}$, Chen LJ, Young AL. Efficacy and safety of topical $\% 0.05$ cyclosporine eye drops in the treatment of dry eye syndrome: A systematic review and meta-analysis. Ocul Surf 2015; 13:213-25.

23. Stevenson D, Tauber J, Reis BL. Efficacy and safety of cyclosporine A ophthalmic emulsion in the treatment of moderate-to-severe dry eye disease: a dose-ranging, randomized trial. The cyclosporine a phase 2 study group. Ophthalmology 2000; 107: 967-74. 
24. Sheppard JD, Donnenfeld ED, Holland EJ, et al. Effect of loteprednol etabonate $0.5 \%$ on initiaition of dry eye treatment with topical cyclosporine $0.05 \%$. Eye \& Contact Lens 2014; 40: 289-96.

25. Singla S, Sarkar L, Joshi M. Comparison of topical cyclosporine alone and topical loteprednol with cyclosporine in moderate dry eye in Indian population. A prospective study. Taiwan J Ophthalmol 2019; 9: $173-8$

26. Food and Drug Administration. Restasis (cyclosporine) ophthalmic label. Available at: https://www.accessdata.fda.gov/drugsatfda_ docs/label/2017/050790s027lbl.pdf

27. Sheppard JD, Scoper VS, Samudre S. Topical loteprednol pretreatment reduces cyclosporine stinging in chronic dry eye disease. J Ocul Pharmacol Ther 2011; 27: 23-7. 